\title{
The IS Undergraduate Curriculum: Predicting Student Outcomes In An Upper Division Programming Course
}

Annette M. Lege, (E-mail: legea@mscd.edu), Metropolitan State College of Denver

Charles H. Mawhinney, (E-mail: mawhinnc@mscd.edu), Metropolitan State College of Denver Joseph S. Morrell, (E-mail: morrellj@mscd.edu), Metropolitan State College of Denver

\begin{abstract}
Academic performance of students is a primary factor in student attrition. Being able to reliably predict academic success would facilitate improved advising for academic program and course selection. This study examines several predictor variables and assesses their value in predicting course performance in an upper division computer programming course in an undergraduate business-based Information Systems (IS) degree program.
\end{abstract}

\section{INTRODUCTION}

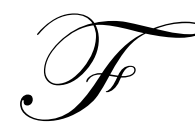

actors affecting student academic success have been widely studied. It is believed that knowledge of valid success predictors can enhance the student advising process and reduce attrition rates. Numerous studies of student performance that have focused on various aspects have been published.

Mawhinney and Morrell (1998) explored the validity of using screening tests to predict student success in an introductory problem-solving course that introduced students to computer programming. They used two instruments: 1) an objective test based on the content of the pre-requisite course, and 2) a Computer Self-Efficacy Scale developed by Murphy, et al (1989). They were unable to establish any predictive validity with either instrument, but went on to suggest that GPA and performance in pre-requisites might be better predictors.

Katz, et al (2003), examined six factors that were believed to be predictors of student success in an introductory computer science course (measured by both grade and knowledge gain). They found that several of these factors correlated with course success: SAT score, pre-test score, time spent on a pre-course tutorial, and various measures of programming accuracy and/or proficiency.

The rapid deployment of online education delivered through the World Wide Web has added another important dimension to the issue of student academic performance. At our institution approximately $10 \%$ of our full-time equivalent student credit hours is delivered through online courses. The question is frequently asked whether learning and success are equivalent for online versus regular classroom courses.

A wealth of research has already been done on final grades, design of Web courses and delivery of hybrid courses. Research has reported the advantages and disadvantages of Web courses, for both students and faculty (Presby, 2001; Mawhinney, et al, 1999). The social aspects of online student behavior have been researched by McCloskey, et al (1998). Burgstahler (1997) found that students participate more in class discussions when the course is delivered electronically than they would in a traditional class. Dager (1998) found that online training and Web-based training can have greater value today because the courses can be much more interactive, and the results can be tracked automatically. Nixon and Leftwich (1998) found that student demand for complete degrees and certificates of training in an online mode was increasing significantly. A study by Kroder, et al, (1998) reported that 8 out of 10 students who responded to a survey of Web course satisfaction said they would take another Internet-based course even though it took more time than a classroom 
course. Differences in final grades between Internet students and classroom students have been found not to be statistically significant by numerous researchers (Bowman, et al, 1995; Haga \& Marold, 2002; Marold \& Haga, 2003; Mawhinney, et al, 1999; Schulman \& Sims, 1999). The differences in performance and achievement among Web students and classroom students have also been analyzed. Achievement, as evidenced by testing was found to be higher in the Web students; however, performance on projects and homework submissions was found to be higher in classroom students and lower in Web students (Marold \& Haga, 2002.). The credibility of courses completed online as opposed to the classroom has also been analyzed (Moreno, Larsen, \& Marold, 2000). Research on the levels of computer literacy by students taking Web courses showed that most students were at a competent level on the Bodker scale, but not at either extreme on the scale-the novice or proficient level. Web literacy and computer literacy in general did not seem to be a barrier to taking an upper level course online (Marold \& Haga, 2002). The midrange achievers in programming courses taken online were found to be the most affected by the distance environment of a Web course (Marold \& Haga, 2003). The attrition rates and failure rates for online courses, and all distance education courses in general, have always been higher than in the classroom. Terry (2001) found that the attrition rates for online MBA courses not only were higher than in the classroom, but as the courses became more analytical and theoretical, the attrition rates increased.

Despite the above studies on Internet courses and their success, there is little on the more subtle aspects of the success or failure of these courses in relation to preparation for subsequent courses. Mawhinney, et al (2005), examined a two-course business statistics sequence to compare the performance of students who took a prerequisite course online versus classroom in the subsequent required course in the CIS major. They were unable to find the anticipated result, believed to be due in great part to the relatively low number of online students in the prerequisite course (23 out of 690 students). However, they did find that the course grade in the subsequent course was positively correlated with numerous other variables:

1. Older students did better than younger students in the subsequent course.

2. Transfer students did better than non-transfer students in the subsequent course.

3. Students with higher GPAs just prior to taking either course did better in the subsequent course.

4. Students with higher grades in the prerequisite course did better in the subsequent.

5. Students who waited longer after completing the prerequisite course did worse in the subsequent course.

6. Students with a higher number of repetitions of either course did worse in the subsequent course.

7. Students who took the classroom version of the subsequent course did better than students who took the online version.

Morris, et al (2004), examined a two-course computer information systems sequence where the first course was an introduction to information systems course required of all business majors, and the second course was an introductory problem solving and programming course required of all CIS majors. They also were unable to find a relationship between delivery mode of the first course and performance in the second course. They did find that the course grade in the subsequent course was positively correlated with numerous other variables:

1. Females did better than males in the subsequent course.

2. Transfer students did better than non-transfer students in the subsequent course.

3. $\quad$ CIS majors did better than non-majors in the subsequent course.

4. $\quad$ Students with higher grades in the prerequisite course did better in the subsequent course.

5. Students who waited longer after completing the prerequisite course did worse in the subsequent course.

6. Students with a higher number of repetitions of either course did worse in the subsequent course.

7. Students with higher GPAs just prior to taking the subsequent course did better in the subsequent course.

8. Students who took the classroom version of the subsequent course did better than students who took the online version. 


\section{METHODOLOGY}

\section{Data Collection}

The institution at which this study was conducted is an undergraduate state institution with a modified open admission policy. The IS program has been very successful and is a key provider of information technology workers in a major metropolitan area whose economy strongly relies on high-tech companies. The number of current majors can be only crudely estimated (approximately 500) because a large percentage of students are part-time, many do not officially declare majors until late in their college careers, and there is no "statute of limitations" to stimulate expeditious progress through the program. Our enrollments have been declining for the past four years, and our annual graduation rate has dropped from a high of about 250 four years ago to approximately 100 students last year. We also have many non-majors who take our minor and/or certificates of completion.

The current study is similar to the one performed by Pence, et al (2003). The prerequisite course (Course B as in basic) in this case is an introductory problem solving and programming course similar to the one used as the subsequent course in the previous study. The subsequent course in this study was an upper division programming course (Course A as in advanced) that requires Course B as a prerequisite. Three consecutive semesters of student data (Spring 2002 through Spring 2003) for Course A were utilized which yielded 128 students in the sample. During this period, two sections of Course A were offered each semester, one online and one in the regular classroom, with approximately equal enrollments. Within a given semester both sections of Course A have been taught by the same instructor, although different instructors have taught it during this period. The following thirteen variables were utilized in this study:

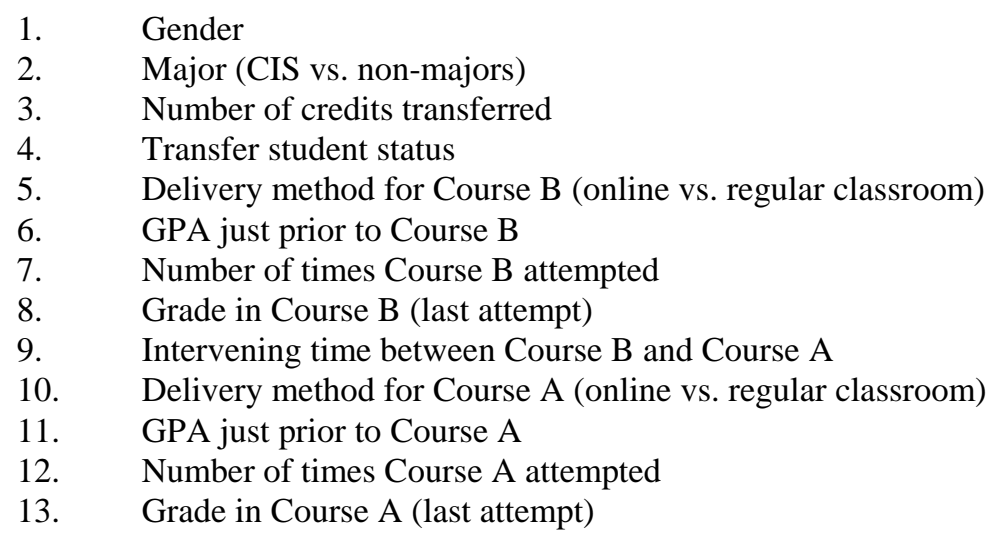

The first twelve variables were the predictor variables, and the dependent variable was the course grade in Course A. The data were obtained by manually retrieving it from our computerized institutional records system.

\section{Sample Characteristics}

Thirty-three percent of the students were females. Eighty-seven percent of the students were declared CIS majors, with the balance being a mix of business, non-business, and IDP (Independent Degree Program) majors.

The grade data for the two courses were converted into equivalent numeric scores ( $\mathrm{A}=4, \mathrm{~B}=3$, etc.). For purposes of this analysis, NC (no credit) grades were treated as being equivalent to F, since these represent students who did attempted the course but did not successfully complete the course. Figures 1 and 2 depict the letter grade distributions for these courses. The grade listed as " $X$ " represents students who either transferred COURSE B or were given a prerequisite waiver so that they could enroll in COURSE A. These students were not assigned any numeric grade for COURSE B in the analysis. The mean grade in COURSE A was 2.59 and the mean grade in COURSE B was 3.31. Although the mean grade in COURSE A was significantly lower, there are several issues which must be pointed out before drawing the conclusion that COURSE A was the more difficult course. COURSE B is the prerequisite to COURSE A and must be passed prior to taking COURSE A, so the students who performed most poorly in the pre-requisite COURSE B 
were never enrolled in COURSE A. (The registration system is admittedly less than perfect in enforcing prerequisites. For example, the system allows a student who failed the prerequisite to register for the second course.) The COURSE B students in this sample were a subset of all students who have taken COURSE B (it is the subset who had also taken COURSE A at the time of data collection). Although COURSE B was a required course in the CIS major, COURSE-A was one of a set of alternative programming courses required in the CIS major, but like COURSE B, it was also taken by many non-majors as an elective or a requirement for a minor or certificate. There was no statute of limitations on these courses, and at the time of this study there was no limit to the number of times a course is attempted. The institution also has a "last grade stands" policy which automatically replaces the student's grade with that received in his/her last attempt.

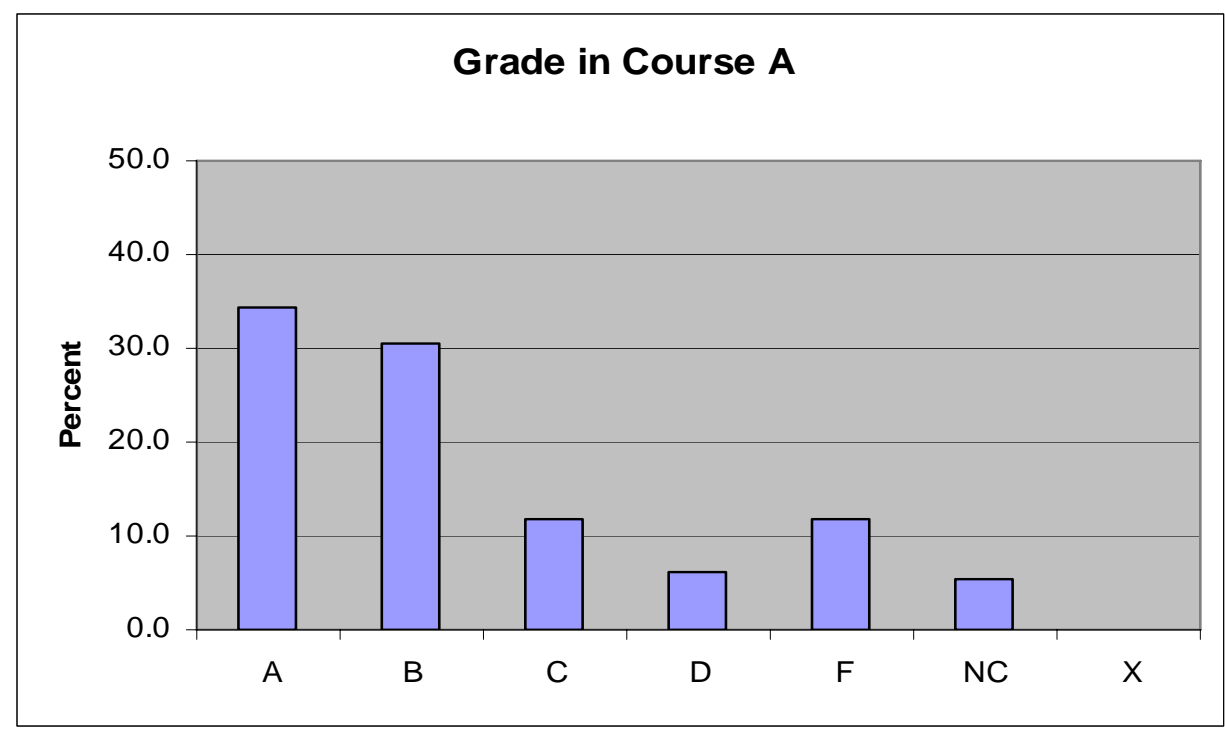

Figure 1: Grade In COURSE A

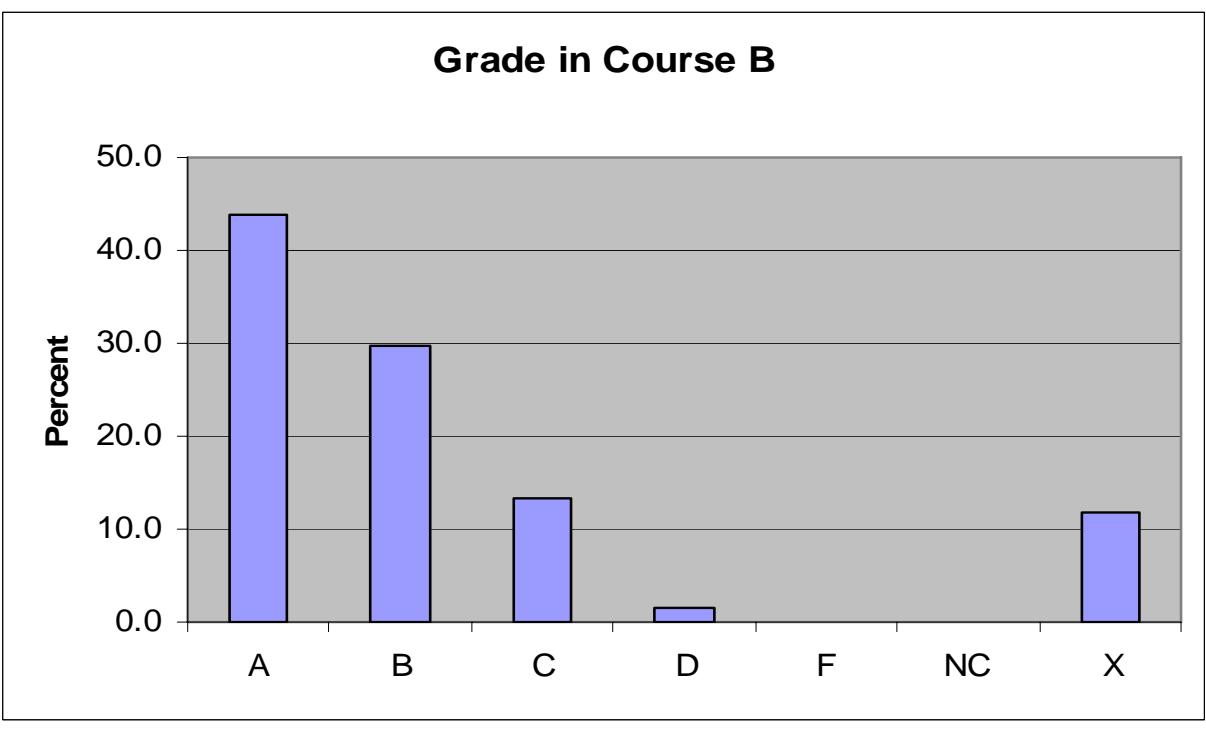

Figure 2: Grade In COURSE B 
Figures 3 and 4 depict the number of times students attempt these two courses. The profiles are very similar and more than $80 \%$ of the students who took either course did not take it more than once.

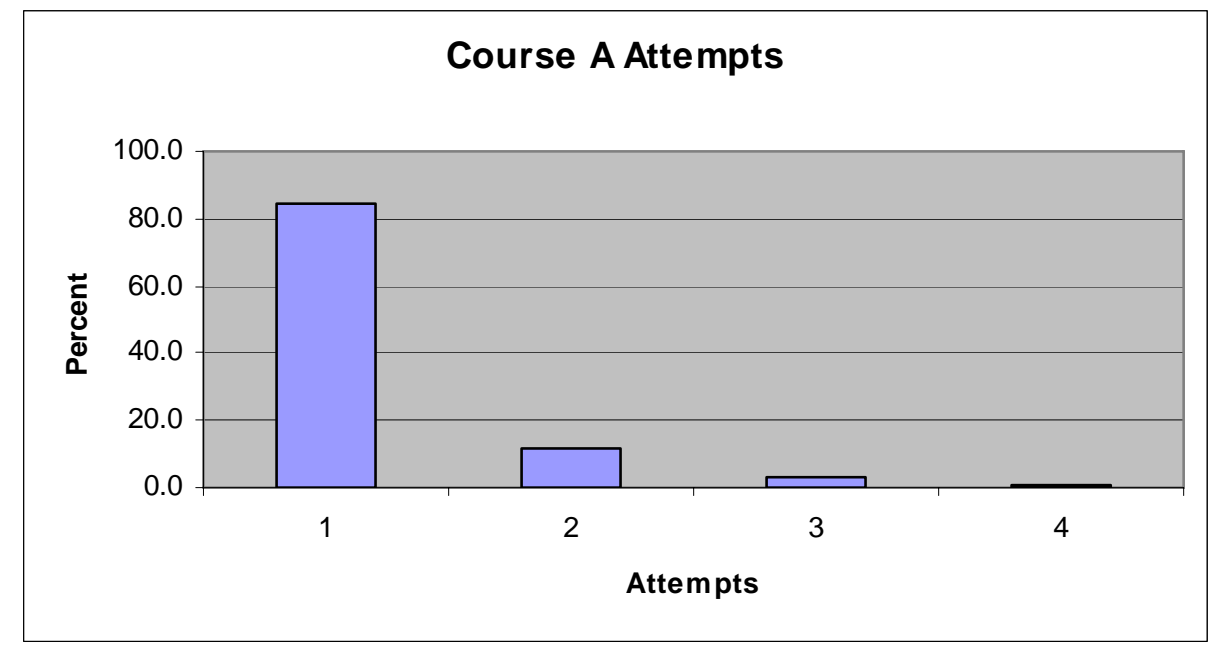

Figure 3: COURSE A Attempts

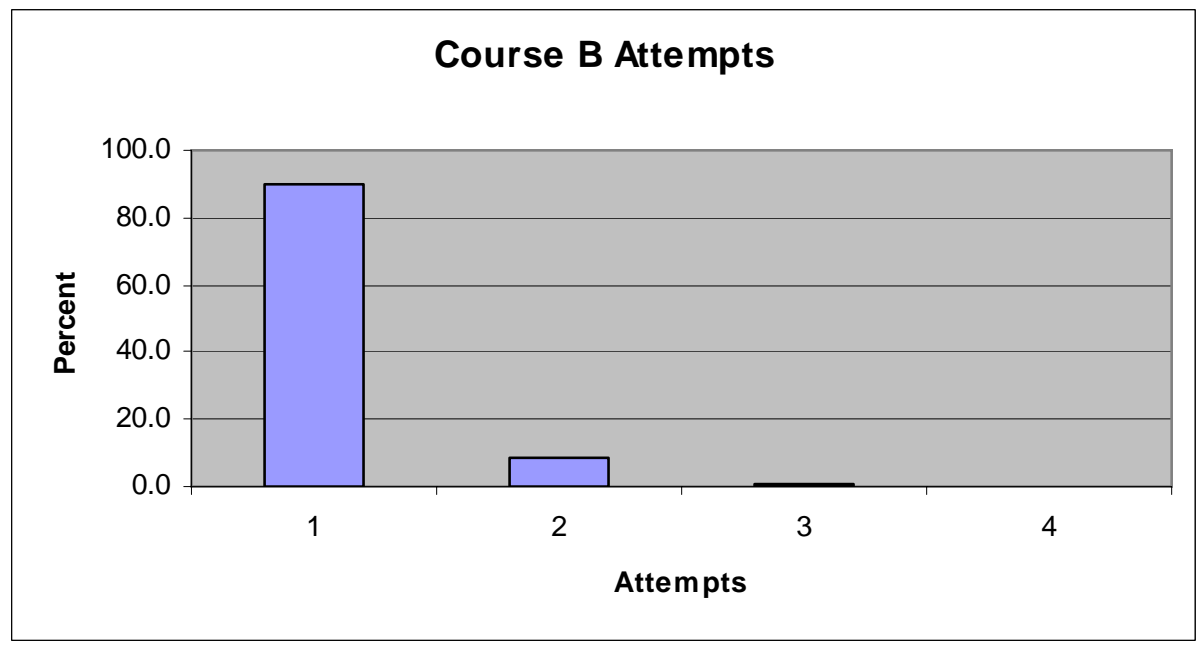

Figure 4: COURSE B Attempts

Figures 5 and 6 depict the GPA distribution of the students just prior to taking COURSE A and just prior to taking COURSE B. Although these distributions look similar, the average GPA (2.97) of students just prior to taking COURSE A was significantly higher than the average GPA (2.75) of students just prior to taking COURSE B. It would be expected that upper division students would have somewhat higher GPAs as weaker students get filtered out in the lower division courses. 


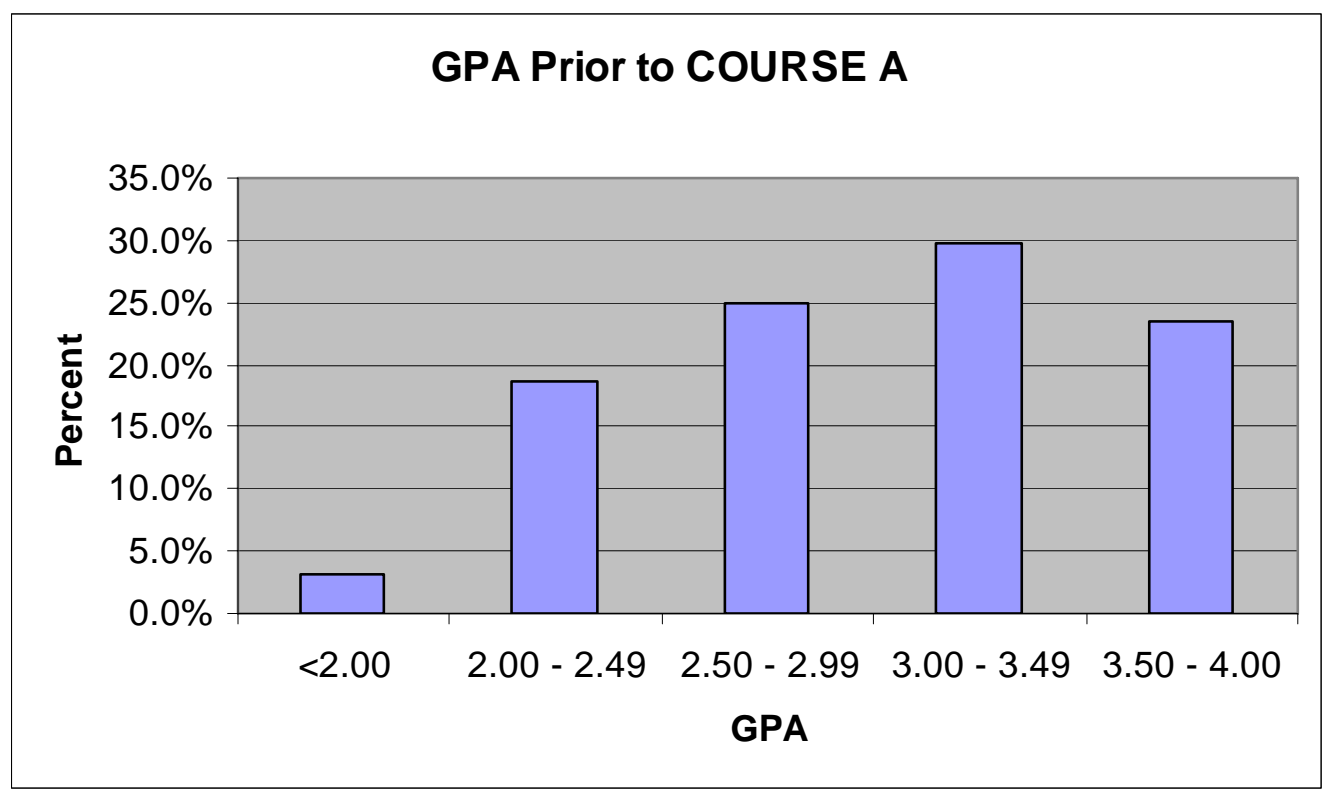

Figure 5: GPA Prior to COURSE A

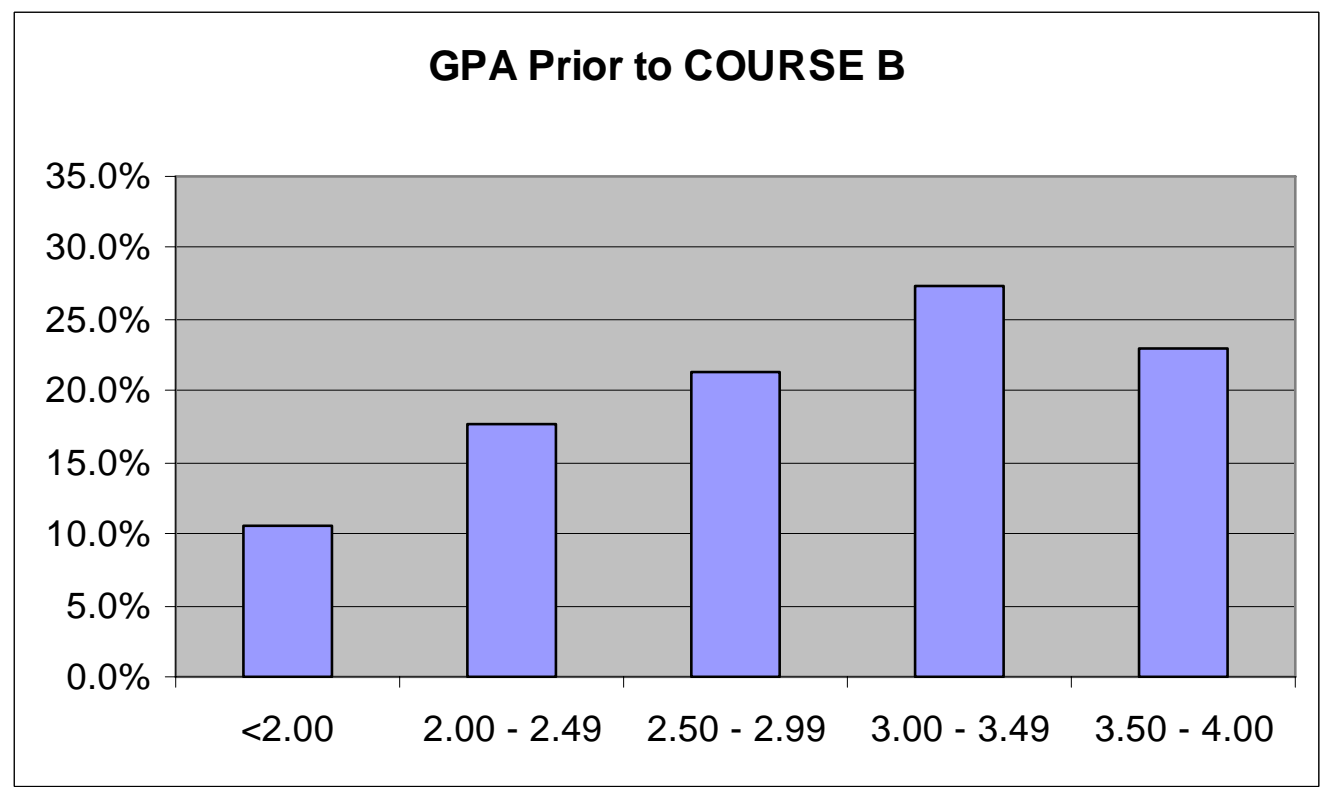

Figure 6: GPA Prior to COURSE B

Figure 7 depicts the distribution of transfer credits. Nearly eighty percent of students in the sample had transferred one or more credits from another institution. This is probably higher than the college average, but is consistent with college data which indicate that the majority of the students at this institution are transfer students from community colleges and other four year institutions. The study by Morris, et al (2004) indicated that transfer students were more successful than non-transfer students in COURSE B. This suggests that it is the non-transfer students that tend to get filtered out in the lower division courses. The authors believe this can be explained by the characteristics the institution's modified open admission policy. Only the more traditional direct entry (out of high school) student under the age of twenty has to meet 
any type of admission standard, but that standard is the lowest in the state for public colleges and universities. Many of these students did not take a college preparatory program in high school. Although many of the transfer students are from community colleges whose admission standards are even lower, the majority of the transfer students are from other fouryear institutions that have higher admission standards. Also, this latter set of transfer students is typically older and has a higher maturity level and commitment to succeed. They also tend to have more work experience.

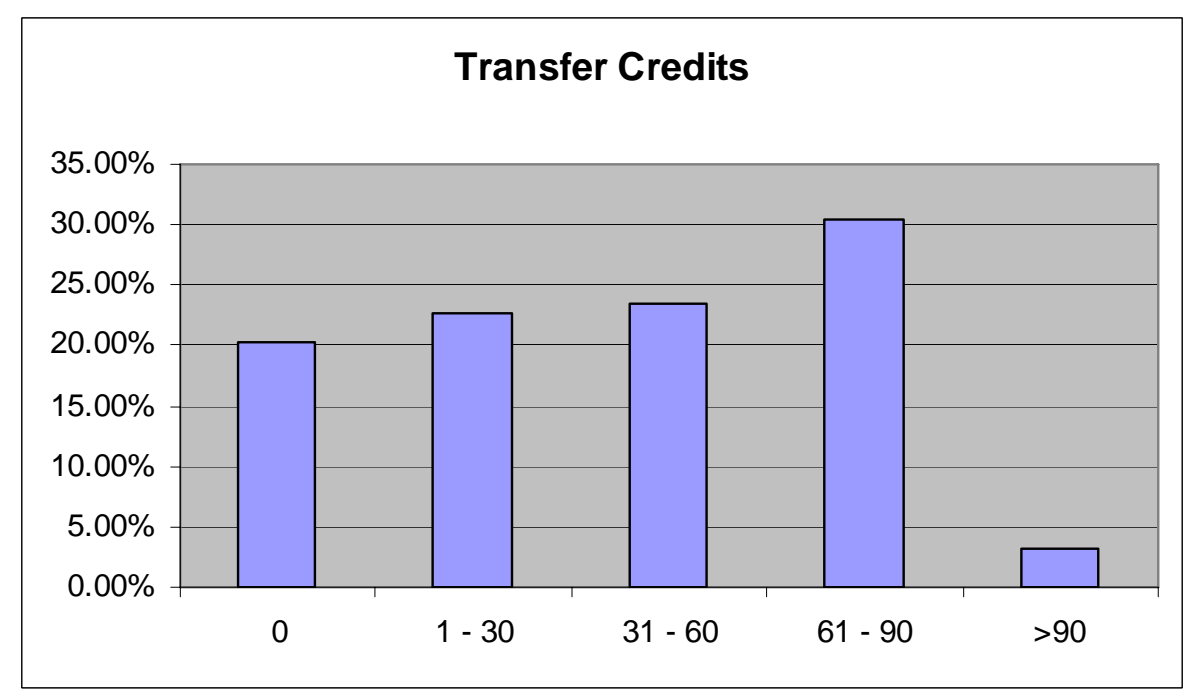

Figure 7: Transfer Credits

Figure 8 depicts the distribution of the time lag between the two courses. A value of one indicates the two courses were taken in immediate succession. Students who took the courses out of sequence or concurrently were not included in the analysis. For purposes of this analysis, summer school was treated as a session equivalent to a regular semester. Less than twenty percent of the students took COURSE B in the session immediately following completion of COURSE A.

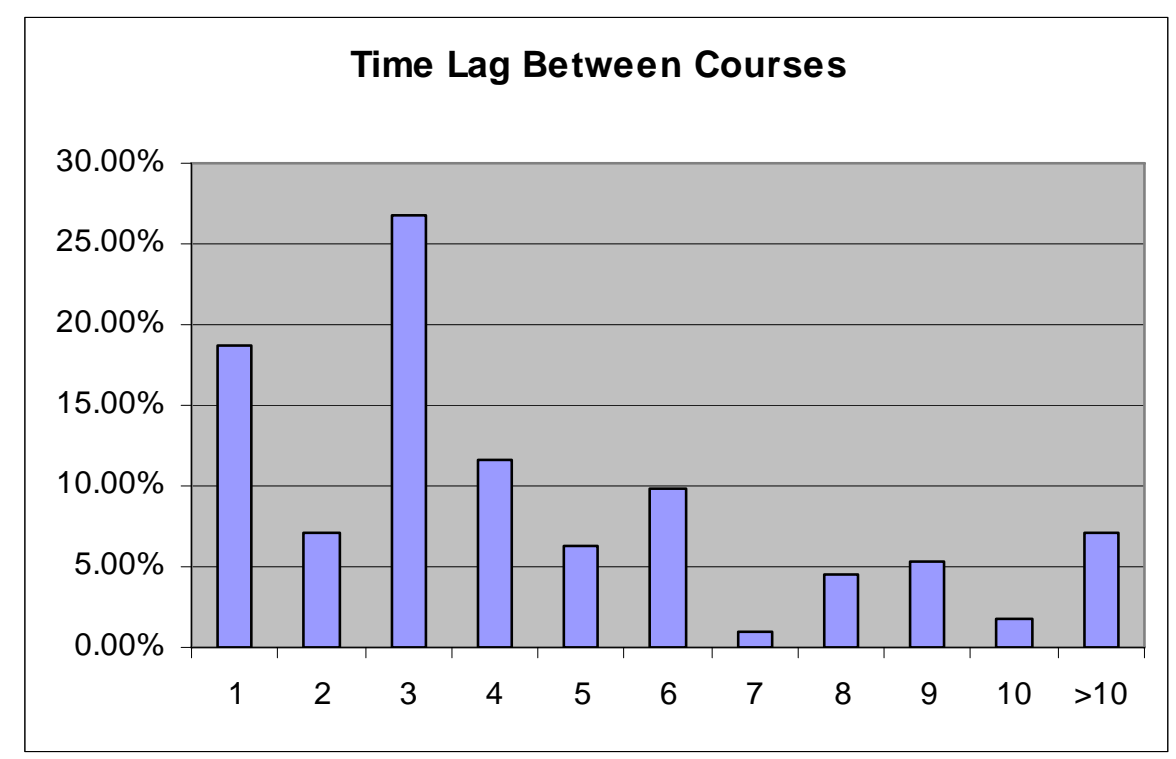

Figure 8: Time Lag Between Courses 


\section{ANALYSIS}

The data were analyzed using the SPSS/PC for Windows statistical package. The correlation of each of the predictor variables with the grade in COURSE A was determined using Pearson coefficients (Anderson, et al, 1994; Norusis, 1993). Table 1 identifies and describes the variables used in this analysis.

\begin{tabular}{|l|l|l|}
\hline \multicolumn{2}{|c|}{ Table 1. Key to Variable Names } \\
\hline Name & Description & Comment \\
\hline gender & Gender (numeric) & $\mathrm{f}=0, \mathrm{~m}=1$ \\
\hline majorn & Major (CIS vs. non-majors) & Major $=1$, non-major $=0$ \\
\hline trhrB & Number of credits transferred (Course B) & \\
\hline trnsfrB & Transfer student status (Course B) & Non-transfer $=0$, transfer $=1$ \\
\hline delvB & Delivery method for Course B (numeric) & classroom = 1, online $=0$ \\
\hline gpaB & GPA just prior to Course B & \\
\hline repB & No. times Course B attempted & \\
\hline grdB & Grade in Course B (numeric, last attempt) & $\mathrm{A}=4, \mathrm{~B}=3, \mathrm{C}=2, \mathrm{D}=1, \mathrm{~F} / \mathrm{NC}=0$ \\
\hline semlag & Semesters between Course A \& B & $1=$ previous semester, etc. \\
\hline delvA & Delivery method for Course A (numeric) & classroom $=1$, online $=0$ \\
\hline gpaA & GPA just prior to Course A & \\
\hline repA & Number of times Course A attempted & \\
\hline grdA & Grade in Course A (numeric, last attempt) & $\mathrm{A}=4, \mathrm{~B}=3, \mathrm{C}=2, \mathrm{D}=1, \mathrm{~F} / \mathrm{NC}=0$ \\
\hline
\end{tabular}

The correlation analysis of the predictor variables is shown in Table 2. Of the twelve pair-wise correlation values, five were statistically significant at $\mathrm{p} \leq 0.05$.

\begin{tabular}{|c|c|c|c|}
\hline Variable & Pearcon Coefficiont & n-value & Siønificance \\
\hline gender & .013 & .892 & Gigmince \\
\hline majorn & .044 & .620 & \\
\hline trhrB & -.052 & .562 & \\
\hline trnsfrB & -.051 & .570 & \\
\hline delvB & .031 & .731 & \\
\hline gраB & .573 & .000 & $* * *$ \\
\hline repB & -.345 & .000 & $* * *$ \\
\hline grdB & .371 & .000 & $* * *$ \\
\hline semlag & -.155 & .103 & \\
\hline delvA & -.083 & .385 & \\
\hline gраA & .288 & .002 & $* *$ \\
\hline repA & -.340 & .000 & $* * *$ \\
\hline
\end{tabular}




\section{COURSE B:}

The following predictor variables had statistically significant $(\mathrm{p}<.052$-tailed) correlations with course grade in

1. Students with a higher number of repetitions of COURSE A did worse in COURSE A.

2. Students with higher GPAs just prior to COURSE A did better in COURSE A.

3. $\quad$ Students with higher grades in COURSE B did better in COURSE A.

4. Students with a higher number of repetitions of COURSE B did worse in COURSE A.

5. Students with higher GPAs just prior to COURSE B did better in COURSE A.

The following predictor variables did not have a statistically significant correlation with course grade in COURSE

A:

1. Gender

2. Whether or not a student was a CIS major

3. Transfer student status

4. Number of credits transferred

5. $\quad$ Time Between Courses

6. Mode of delivery (classroom versus online) in either course

\section{DISCUSSION AND CONCLUSIONS}

An interesting finding is that delivery mode (online versus classroom) for the prerequisite course (COURSE B) did not affect the student's performance in COURSE B itself, nor the student's performance in the subsequent course (COURSE A). Nor did the delivery mode of COURSE A seem to affect the performance in COURSE A. This was not the result that was anticipated, although it was consistent with the results for an IS course sequence published by Morris, et al (2004).

Many of the possible reasons for this outcome that were proposed by Morris, et al (2004) would not be relevant in this instance. The two courses in the sequence used in this study were very similar to each other in terms of problemsolving orientation and student assessment methodology. The fact that there was not a significant difference found in performance in COURSE B based on delivery mode is not consistent with other previous research that has shown that students perform worse in online classes when the course requires higher level analytical thinking and problem solving. It should also be noted, that even though the data covered a one-and-a-half year period and that the prerequisite course had been offered online throughout this period and for many previous years (with well over a hundred students successfully completing it in that mode), there were only 13 students in this sample who had completed COURSE B in an online mode.

An important finding was that the performance in the prerequisite COURSE B and performance in COURSE A was highly significant, providing the highest correlation coefficient of any in this study. This would seem to validate that while the delivery mode of neither course is important, it is important for COURSE B to be a prerequisite for COURSE A.

Other research findings in this study confirm what one would expect. Students with higher GPAs prior to taking either course performed better in COURSE A. Students that did not complete either course successfully on the first attempt performed worse in COURSE A.

It was unexpected that the time lag between courses was not significant. This was contrary to the findings of Morris, et al (2004) and Mawhinney, et al (2005). It is suspected that perhaps the model used in the current study was not sufficiently complete. COURSE A is one of several courses that CIS majors can use to meet the programming requirement, and many students take more than one of these courses, using them as electives. These other courses were not included in this study.

Transfer students performed no better than non-transfer students in COURSE A. This reinforces the premise that the aforementioned transfer student effect shows up most strongly in lower division courses. 


\section{REFERENCES}

1. Anderson, D. R., Sweeney, D. J., and Williams, T. A. (1994). Statistics for Business and Economics, 5th ed. Minneapolis/St. Paul: West Publishing Co.

2. Bowman, B. J., et al. (1995). Teaching End User Applications with Computer-based Training. Theory and an Empirical Investigation. Journal of End User Computing. 7:2, 12-17.

3. $\quad$ Burgstahler, S. (1997). Teaching on the Net: what's the Difference? T.H.E. Journal. 24:9. 61-64.

4. $\quad$ Dager, N. (1998). Little Web Schoolhouse. AV Video Multimedia Producer. 20:12. 15.

5. Gass, S. I., Hirshfield, D. S., and Wasil, E. A. (2000). Model world: the spread sheeting of or/ms. Interfaces, 30(5), Sept-Oct, 72-81.

6. Haga, W. and Marold, K. (2002). Is the Computer the Medium and the Message? A Comparison of Student VB Programming Performance in Three Delivery Modes. The International Business and Economics Research Journal. 1:7. 97-104.

7. Katz, S., Aronis, J., Allbritton, D., Wilson, C., and Soffa, M. L. (2003). A study to identify predictors of achievement in an introductory computer science course. Proceedings of the SIGMIS Conference. April 1012, Philadelphia, pp. 157-161.

8. $\quad$ Kroder, S. L., Suess, J. and Sachs, D. (1998). Lessons in Launching Web-based Graduate Courses. T.H.E. Journal. 25 :10. 66-69.

9. Marold, K. and Haga, W. (2002). Measuring Online Students’ Ability to Apply Programming Theory: Are Web Courses Really Working? Proceeding of the Thirty-First Western Decision Sciences Institute Meeting. Las Vegas, N.V.

10. Marold, K. and Haga, W. (2003). The Emerging Profile of the Online Learner: Relating Course Performance with Pre-tests, GPA, and other Measures of Achievement. Proceedings of International Resource Management Conference. Philadelphia, PA. May 18-21.

11. Mawhinney, C. and Morrell, J. (1998). The IS Undergraduate Curriculum: Predicting Student Outcomes in the IS97.5 Course (Programming, Data, File and Object Structures). Proceedings of the 1998 ACM SIGCPR Conference. Boston, MA, May 26-28, 133-135.

12. Mawhinney, C. H., Helms, S., Khandekar, R., Larsen, G., Marold, K., Parker, V. \& Uliss, B.. (1999). Issues in Putting the Business Curriculum Online. Proceedings of the Western Decision Sciences Institute. Puerto Vallarta, MX. April.

13. Mawhinney, C, Pence, N., Fustos, J., Haga, W., Marold, K., Moreno, A., Morrell, J., and Morris, G., (2005). Factors that impact student performance in an advanced business course. Proceedings of the 2005 International Business \& Economics Research Conference, October 3-7, Las Vegas, Article \#362.

14. McCloskey, D., et al. (1998). Web-based vs. Traditional Course Deployment: Identifying Differences in User Characteristics and Performance Outcomes. Proceedings of IBSCA Conference. Denver, CO. July, 1998.

15. Moreno, A., Larsen, G. and Marold, K. (2000). The Credibility of Online Learning: A Statistical Analysis of IS Course Delivery at Three Levels. Proceedings of the Western Decision Sciences Institute. Maui, HI.

16. Morris, G., Mawhinney, C, Fustos, J., Morrell, J., Pence, N., Marold, K. and Moreno, A. (2004). Factors that impact student performance in a course sequence. Communications of the International Information Management Association, 4: 1. 63-79.

17. Murphy, C. A., Coover, D., \& Owen, S. V. (1989). Development and validation of the computer selfefficacy scale, Educational and Psychological Measurement, v 49, 893-899.

18. Nixon, M. A., and Leftwich, B. R. (1998). Leading the Transition from the Traditional Classroom to a Distance Learning Environment. T.H.E. Journal. 2 :6. 54-57.

19. Norusis, M. H. (1993). SPSS for Windows Base System User's Guide Release 6.0. Chicago: SPSS, Inc.

20. Pence, N., Morrell, J., Fustos, J., Haga, W., Marold, K.., Mawhinney, C, Moreno, A., and Morris, G. (2003). An Exploration of the Impact of Online Delivery in Prerequisite Courses in CIS Major's Course Sequence. Proceedings of the International Business \& Economics Research Conference, Las Vegas, NV.

21. Presby, L. (2001). Increasing Productivity in Course Delivery. T.H.E. Journal. 28 :7. 52-58.

22. Schulman, A. and Sims, R. L. (1999). Learning in an Online Format versus an In-class Format: An Experimental Study. T.H.E. Journal. 26 :11. 54-56.

23. Terry, N. (2001). Assessing Enrollment and Attrition Rates for the Online MBA. T.H.E. Journal. 28:7. 64-68. 